\title{
SOBRE OS SONHOS E O SURREALISMO: THEODOR ADORNO E ANDRÉ BRETON
}

\author{
JORGE DE ALMEIDA
}

Universidade de São Paulo

\begin{abstract}
Resumo
O ensaio investiga os pressupostos filosóficos e críticos de dois modos de conceber a representação literária dos sonhos, contrapondo as obras de André Breton ao livro de protocolos oníricos de Adorno, com o objetivo de refletir sobre o sentido do surrealismo e as relações entre arte, sociedade e psicanálise.
\end{abstract}

Palavras-chave

Theodor Adorno; André Breton; surrealismo; sonhos; Sigmund Freud.

\begin{abstract}
With the aim of reflecting about the meaning of surrealism and the relations between art, society, and psychoanalysis, this essay investigates the philosophical and critical tenets of two modes of conceiving the literary representation of dreams, by comparing André Breton's works to Adorno's book of dream notes (Traumprotokolle).
\end{abstract}

Keywords

Theodor Adorno; André Breton; Surrealism; dreams; Sigmund Freud.

Bons leitores de Hegel, tanto André Breton quanto Theodor Adorno reconheciam, cada um a seu modo, que a dialética exige a visada retrospectiva, na qual as contradições do passado, só perceptíveis sob a luz incerta do crepúsculo, poderiam ser revistas a partir de uma distância histórica supostamente mais justa, ainda que por vezes cruel. Entretanto, foi o próprio Breton, ao discutir a nova posição política do surrealismo em 1935, quem invocou Hegel (não tanto como filósofo sistemático oficial, o que também era, mas como autor de uma Estética que concebia a arte como um modo específico de conhecimento, para além da autoconsciência do sujeito racional) e o entronizou sem ironia como possível juiz antecipado do movimento: "Declaro que, ainda hoje, é a Hegel que se há de interrogar sobre os bons e os maus fundamentos da atividade surrealista nas artes. Somente ele poderá dizer se esta atividade estava predeterminada no tempo, somente ele poderá ensinar-nos se a sua duração futura tem a possibilidade de vir a ser contada em dias ou em séculos". ${ }^{241} \mathrm{Nem}$ tanto, nem tão pouco; o necessário envelhecimento (assumido pelo próprio Breton em seus textos finais) acabou sendo antecipado pelo horror da Segunda Guerra Mundial, perante a qual os choques surrealistas dificilmente podiam defender seu aspecto lúdico e infantil, que nos anos 1920 ainda era motivo de orgulho. É a partir dessa perspectiva sombria que Adorno revê o surrealismo, em um importante ensaio de 1956, recolhido no primeiro volume das Notas de literatura. ${ }^{242} \mathrm{O}$ olhar retrospectivo do crítico não esconde uma certa nostalgia, pois o texto

\footnotetext{
${ }^{241}$ André Breton, "Position politique du Surréalisme", in Oeuvres complètes II, Paris, Gallimard, 1992, p. 476. Edição brasileira em André Breton, Manifestos do surrealismo, trad. Sergio Pachá, Rio de Janeiro, NAU, 2001, p. 310 .

${ }^{242}$ Theodor W. Adorno, "Revendo o surrealismo", in Notas de literatura I, trad. Jorge de Almeida, São Paulo, Editora 34, 2003, p.135-140.
} 
pode ser lido como um capítulo adiado, mas já previsto, no conjunto de sua contínua reflexão sobre a arte moderna, cujos dilemas eram acompanhados de perto desde a década de 1920, justamente quando o surrealismo, herdeiro de Dada, abalou desde fora a já conturbada cena da República de Weimar.

O objetivo declarado do ensaio de Adorno era problematizar a "teoria corrente sobre o movimento", segundo a qual "os sonhos jogariam com os elementos da realidade da mesma maneira que os procedimentos do Surrealismo". ${ }^{243}$ Criticando a abordagem usual das "composições" surrealistas (pois a própria noção de "obra" deve ser aqui matizada) como meras "ilustrações literárias e gráficas de Jung ou Freud", Adorno valoriza os procedimentos artísticos que as embasam, tanto na teoria dos manifestos quanto na prática, ainda que indistinta, de suas conseqüências. Assim, a montagem e a colagem, o acaso e a escrita automática adquirem um sentido próprio, na busca de uma linguagem imagética capaz de dar voz ao inconsciente e aos temas reprimidos, almejando um "ditado do pensamento" que, como defendia Breton, suspenderia "qualquer controle exercido pela razão", sendo "alheio a qualquer preocupação estética ou moral" "44 (embora o próprio movimento tenha logo reconhecido as contradições dessa intenção inicial, assumindo dialeticamente seu comprometimento estético e político). No ensaio de 1956, Adorno reconfigura o problema, buscando salvaguardar o sentido mais amplo da eventual "técnica" surrealista, que se configurava como reflexão propriamente estética, mesmo se as vanguardas pretendiam, em tese, diminuir a distância que afastava a arte da vida: "Os próprios surrealistas descobriram que as pessoas não realizam livres associações da mesma maneira que eles escrevem, nem mesmo na situação psicanalítica". 245

No caso da relação essencial do movimento com os sonhos, a distinção entre "procedimentos artísticos" e "experimentos psíquicos" é ainda mais complexa, e acompanha os encontros e desencontros de André Breton com a psicanálise freudiana. ${ }^{246} \mathrm{Em}$ um primeiro momento, a filiação é assumida com humildade: "Cumpre sermos gratos às descobertas de Freud. Baseada nelas delineia-se, enfim, uma corrente de opinião graças à qual o explorador humano poderá ir mais longe em suas investigações, uma vez que está autorizado a não levar em conta tão-somente as realidades sumárias". ${ }^{247}$ O esforço comum de "exploração" parece aproximar o artista e o cientista, pois ambos têm como objeto de pesquisa justamente o sonho (Breton chega a cumprimentar Freud por ter despertado o interesse científico pelo assunto ${ }^{248}$ ). Quase não se distingue qual dos dois é mais enfático, nesse momento, no projeto de submeter a atividade onírica a um "exame metódico", que finalmente tornaria possível "a descrição do sonho em sua inteireza". " ${ }^{449}$ entanto, as divergências já se anunciam em Nadja, de 1928, quando Breton começa a estabelecer distinções importantes entre suas intenções propriamente artísticas e a teoria analítica de Freud: "[...] não se vá deduzir daí imediatamente que eu seja, em tudo e por tudo, passível de psicanálise, método que aprecio embora pense que ela visa apenas a expulsar o homem de si mesmo, e da qual espero um alcance superior às meras

\footnotetext{
243 Idem, ibidem, p. 135.

${ }^{244}$ André Breton, "Manifeste du surrealisme", in Oeuvres complètes I, Paris, Gallimard, 1988, p. 328. Edição brasileira em André Breton, Manifestos do surrealismo, op. cit., p. 40.

${ }^{245}$ Th. W. Adorno, "Revendo o surrealismo”, op. cit., p.136.

246 Peter Bürger, na década de 1970, já citava uma extensa bibliografia sobre a relação entre Freud e os surrealistas (cf. Der französiche Surrealismus, Frankfurt am Main, Suhrkamp, 1996, p. 84). Sobre a conturbada relação pessoal e teórica entre Freud e Breton, cf. Jacqueline Chénieux-Gendron, O surrealismo, São Paulo, Martins Fontes, 1992, p. 207-8.

${ }^{247}$ A. Breton, "Manifeste du surrealisme", op. cit., p. 316; ed. bras., op. cit., p. 23.

248 "Foi com inteira razão que Freud fez dos sonhos objeto de seu estudo crítico": A. Breton, "Manifeste du surrealisme", op. cit., p. 317; ed. bras., op. cit., p. 24.

${ }^{249} \mathrm{O}$ texto, que sem nenhuma modificação talvez pudesse ter sido assinado por Freud, é no entanto de Breton, em "Manifeste du surrealisme", op. cit., p. 319; ed. bras., op. cit., p. 27-8.
} 
funções de meirinho". ${ }^{250}$ Daí em diante, tanto nas obras literárias quanto nas pictóricas, os surrealistas oscilam entre considerar o "mundo onírico" como "matéria" para a composição artística ou tomá-lo como modelo de uma nova concepção de forma, capaz de configurar esteticamente os destroços da realidade externa ou psíquica. Peter Bürger, em seu importante estudo sobre o surrealismo, ${ }^{251}$ sistematiza em três pontos o papel dos sonhos no movimento: em primeiro lugar, deve-se reconhecer um esforço de expor e reproduzir a "lógica" peculiar aos sonhos, contrapondo-a à lógica da razão em vigília; em segundo, o sonho proveria acesso privilegiado ao inconsciente, local onde se poderia salvar, no contexto da civilização, os momentos por ela reprimidos ou esquecidos; por fim, haveria ainda uma tentativa de reintegração do sonho na vida, com perspectivas libertárias. Nessa sua primeira abordagem, Peter Bürger privilegia o momento propriamente estético do problema, focalizando a crise que levaria à ruptura com a própria "instituição arte" (conceito que norteia seu livro seguinte, a Teoria da vanguarda). Desvalorizando a contribuição da teoria psicanalítica, ele concentra seu estudo em um desenvolvimento interno à própria tradição literária: "Para a gênese da teoria dos sonhos desenvolvida no Manifesto, mais importante do que Freud foi Nerval, especialmente com sua Aurélia". ${ }^{252}$

Adorno não foi tão longe, mas também reconheceu a ambigüidade da questão, sempre buscando contrapor a intenção teórica (em alguma medida compartilhada com Freud) aos resultados artísticos efetivamente "conseguidos" pelos surrealistas: "Não é assim que se sonha, ninguém sonha desse modo". ${ }^{253}$ Afirmação peremptória, pouco ao estilo do crítico, que não desenvolve no ensaio uma teoria própria do sonho, permanecendo próximo às idéias apresentadas por Freud na Traumdeutung. O que lhe interessa é uma questão de ampla relevância para o debate crítico sobre a arte moderna e as vanguardas: a tensão entre a expressão direta da subjetividade e a necessária objetividade dos meios de representação. Isso explica a ênfase no estudo dos procedimentos executados pelas obras de inspiração onírica, e não na teoria dos sonhos propriamente dita. A pintura e a literatura surrealistas desenvolvem um processo geral de deslocamento, tanto de sentido quanto de contexto e uso de objetos, além de aproximações imagéticas de figuras, palavras e idéias contrastantes ou meramente distantes. Como exemplo, basta lembrar os quadros mais conhecidos de Salvador Dali ou René Magritte, nos quais, mesmo em um contexto vanguardista, o princípio da figuração precisa permanecer válido, para que o espectador possa reconhecer os elementos combinados "segundo a lógica surrealista". Nesse ponto, podemos argumentar que há uma diferença entre a literatura e a pintura, já que essa última pode ser vista como um retrocesso do ponto de vista formal, em comparação com a pintura mais avançada do abstracionismo expressionista ou mesmo do cubismo radical. Adorno não toca nesse problema, mas afirma que, no conjunto da produção surrealista, haveria "decomposição e rearranjo, mas não dissolução". ${ }^{254}$ Mesmo que os procedimentos sejam análogos ao modo de funcionamento dos sonhos, como descrito por Freud, há uma diferença importante: "O sujeito, que no Surrealismo age de maneira muito mais aberta e desinibida do que nos sonhos, concentra sua energia justamente na autoextinção, o que no sonho não requer nenhuma energia". ${ }^{255}$ Qualquer procedimento artístico, por mais que tenha como propósito o cancelamento da distância entre arte e vida ou entre lógica e acaso, não pode ser visto como um ato espontâneo, e esse esforço do sujeito para, conscientemente, deixar aflorar o inconsciente, saindo de cena (e isso é previsto e louvado nos manifestos), acaba revertendo, para Adorno, em expressão da objetividade transfigurada pelas

\footnotetext{
${ }^{250}$ André Breton, Nadja, in Oeuvres complètes I, Paris, Gallimard, 1988, p. 653. Ed. bras. Nadja, trad. Ivo Barroso, Rio de Janeiro, Imago, 1999, p. 25.

${ }^{251}$ P. Bürger, Der französiche Surrealismus, 2. ed. rev. aum., Frankfurt am Main, Suhrkamp, 1996, A primeira edição do livro é de 1971.

${ }^{252}$ Idem, ibidem, p. 86.

${ }^{253}$ T. W. Adorno, "Revendo o surrealismo", op. cit., p. 136.

${ }^{254}$ Idem, ibidem, p. 136

${ }^{255}$ Idem, ibidem
} 
intenç̃es do sujeito. Isso explica o segundo passo do argumento: "Mas por isso mesmo tudo aparece mais objetivamente, por assim dizer, do que no sonho, onde o sujeito, ausente desde o início, dá novas cores e permeia tudo o que encontra nos bastidores" ${ }^{256}$ O ensaio termina com a paradoxal e surpreendente aproximação entre o Surrealismo e a Neue Sachlichkeit [Nova objetividade]. Pois o desejo neo-objetivista de dar conta da realidade como um todo, sem intromissão ativa do sujeito, encontraria justamente na prática surrealista seu complemento (e aqui poderíamos também lembrar as afinidades, na década de 1920, entre o neoclassicismo francês e os surrealistas). Adorno dá ainda outro passo: o sentido da realidade, mediada pelo acaso e outros procedimentos surrealistas, seria mais amplo do que na suposta realidade objetiva buscada pelos alemães: "O Surrealismo recolhe o que a Neue Sachlichkeit recusa aos homens; as deformações testemunham o efeito da proibição no que um dia foi desejado". Se o que é desejado também é reprimido, sua representação posterior, em modo análogo ao procedimento que Freud reconheceu nos sonhos, é afetada por isso.

A questão passa ao "como representar", em um processo submetido certamente às características desse novo objeto, o sonho, que num primeiro momento escapa ao controle do sujeito, justamente por se referir ao que ele tem de mais íntimo. O próprio Breton tinha consciência disso, quando destacava o papel fundamental da técnica para a reconstituição artística dessa realidade mais completa, porque não cindida entre o consciente e $\mathrm{o}$ inconsciente, entre o permitido e o reprimido. Essa intenção reaproxima a arte da ciência:

Se as profundezas do nosso espírito ocultam forças estranhas, capazes de aumentar as da superfície ou de lutar vitoriosamente contra elas, é de todo interesse captálas primeiro, para em seguida submetê-las, se possível, ao controle da nossa razão [...]. Mas é importante observar que nenhum meio é designado a priori para a condução dessa empresa; que, até segunda ordem, ela pode passar por ser tanto do domínio dos poetas como dos cientistas $[\ldots]^{257}$

Nesse sentido, os procedimentos artísticos surrealistas eram marcados tanto pelo impulso quase científico (que assumia certamente ares metafísicos em razão do alcance do objeto) de conhecer o modo como a realidade aparecia mediada no sonho quanto pela dificuldade em representar, nas obras, o aspecto surreal (justamente "para além" da realidade) configurado no mundo onírico.

Essa discussão já seria suficientemente interessante, mas torna-se crucial quando levamos em conta o fato de Adorno ter anotado sistematicamente seus sonhos, por quase toda a vida. Um pequeno conjunto desses protocolos foi publicado na revista Aufbau, durante o exílio americano. Outros foram recolhidos a partir de uma cópia datilografada, originalmente destinada à publicação, e reproduzidos no último volume dos Gesammelte Schriften, com o seguinte aviso: "Esses protocolos de sonhos, escolhidos de um acervo mais amplo, são autênticos. Eu os escrevi logo ao acordar, e para a publicação foram corrigidos apenas os mais sensíveis defeitos de linguagem" ${ }^{258}$ Em 2005, uma parte ainda maior desse acervo foi publicada, como volume da coleção "Edition Suhrkamp", com organização de Christoph Gödde e um interessante posfácio de Jan Philipp Reemtsma, importante crítico literário e multimilionário patrocinador dos arquivos que guardam o Nachlass de Adorno. ${ }^{259} \mathrm{O}$ livro inclui, além dos protocolos publicados anteriormente, um total de 109 sonhos, escritos entre janeiro de 1934 e abril de 1969, poucos meses antes de sua morte.

A leitura desse surpreendente volume constitui um desafio, pois além do conteúdo dos próprios sonhos, até mesmo a forma final e intenção primeira de sua publicação abrem espaço

\footnotetext{
${ }^{256}$ Idem, ibidem.

${ }^{257}$ André Breton, “Qu'est-ce que le surréalisme?”, in Oeuvres complètes II, Paris, Gallimard, 1992, p. 241-2.

258 Theodor W. Adorno, "Traumprotokolle”, in Gesammelte Schriften 20, Frankfurt am Main, Suhrkamp, 1986, p. 572-82.

${ }^{259}$ Idem, Traumprotokolle, Frankfurt am Main, Suhrkamp, 2005.
} 
para diferentes abordagens. Reemtsma, cauteloso em seu posfácio, logo exclui a utilização do material como meio de análise do próprio Adorno, com um argumento bem fundamentado:

A interpretação psicanalítica de um sonho é um processo dialógico entre duas pessoas, na qual a comunicação das associações feitas por aquele que relata o sonho tem um papel decisivo. Apenas ela permite a localização biográfica da vivência do sonho, e nessa localização biográfica consiste essencialmente sua interpretação. ${ }^{260}$

Essa perspectiva é propriamente freudiana, basta lembrar que já na Traumdeutung o relato protocolar de cada sonho é relacionado com as experiências infantis do analisando, expostas ao leitor por meio da voz narrativa do analista. Somente assim seria possível acompanhar e entender as interpretações propostas por Freud para cada caso. Tendo descartado a referência biográfica, Reemtsma opta por uma breve contextualização dos protocolos, e depois se concentra em uma instigante leitura (cuidadosamente apresentada como "pessoal") de alguns temas e sonhos específicos, cujo sentido é ampliado pelas ressonâncias encontradas na filosofia do próprio Adorno. Nosso caminho aqui será outro: em um jogo de espelhos ao gosto dos surrealistas, mas também sempre cultivado pela dialética, seria talvez frutífero contrapor o livro de Adorno (e a própria intenção de publicá-lo) às suas reflexões sobre o modo como o sonho havia sido incorporado pelos surrealistas.

A primeira questão relevante, já que estamos lidando com o estudo dos sonhos de quem afirma que os "procedimentos artísticos" constituem o interesse maior do surrealismo, refere-se ao controverso caráter literário de um protocolo onírico apresentado como tal. Em Breton, antes do Manifesto, a recriação literária dos sonhos se distanciava do tom protocolar, inspirando-se nas tentativas românticas de dar valor estético à experiência, tanto na recriação de sua "atmosfera" quanto na exposição dos elementos narrativos que lhe conferiam sentido, por mais absurdo que fosse. Isso fica claro no conjunto de cinco sonhos que abre o livro Clair de Tierre, ${ }^{261}$ publicado em 1923. Já em Nadja, de 1928, a reflexão do narrador sobre seus sonhos passa a segundo plano, diante da personagem que encontra nas ruas de Paris, "alma errante" que vive entre a realidade e a ilusão, limite que a própria forma do livro, com suas múltiplas associações e reproduções fotográficas, pretende mimetizar. Os sonhos voltam a ser o ponto central na obra Les vases communicants, de 1932, que combina reflexões teóricas e tentativas práticas de elucidar tanto a possibilidade de interpretação dos sonhos quanto o modo como eles podem reinterpretar a realidade. Na primeira parte do livro, que interessa a nosso ensaio, os protocolos de sonhos ("notation immédiate") são submetidos à análise linha a linha, revelando ao leitor a forma pela qual os "conteúdos" externos são re-elaborados no mundo onírico. ${ }^{262}$ Assim, a própria forma da notação imediata é motivo de reflexão, já que não se tem acesso ao sonho senão por meio dela. Mas a mera transcrição parece ser insuficiente; as imagens geradas têm necessariamente de ser interpretadas, mesmo a custo de uma variedade de hipóteses contraditórias. Cada uma recupera um pequeno detalhe ou experiência vivida, e as múltiplas referências vão se acumulando, em uma montagem que se abre para novas associações e transporta, no esforço de interpretação (tanto reflexivo quanto literário), a lógica do sonho para a própria lógica narrativa.

No caso do livro de Adorno, nenhuma interpretação é oferecida, e a nota que acompanha a primeira iniciativa de publicação ainda ressalta, como vimos, a "autenticidade" da transcrição dos sonhos. Ora, sabemos desde Freud que a própria configuração do sonho em um protocolo já inclui um processo de "dar forma" ao que foi sonhado. O processo de "elaboração" dos sonhos (cujo termo original "Bearbeitung" mantém mais próxima a relação com o tipo específico de "trabalho" [Arbeit] exigido para a reconfiguração das imagens

\footnotetext{
${ }^{260}$ Idem, ibidem, p. 108.

${ }^{261}$ André Breton, "Clair de Tierre: cinq rêves", in Oeuvres complètes I, Paris, Gallimard, 1988, p. 149-55.

${ }^{262}$ Idem, "Les vases communicants", in Oeuvres completes II, Paris, Gallimard, 1992, p. 103-46.
} 
oníricas) havia sido apresentado por Freud como uma satisfação às condições de "segunda instância", que possibilitam o relato: "É natural que nosso pensamento de vigília queira criar ordem nesse material, produzindo relações e conformando-o a nossas expectativas de um nexo inteligível [intellegiblen Zusammenhanges]". ${ }^{263}$ De fato, a mera exposição discursiva do sonho (fenômeno fundamentalmente imagético), seja ela com intenção evidentemente literária ou simplesmente protocolar, gera um novo objeto, que já inclui em si um aspecto reflexivo (consciente ou não, como atestam as possibilidades de lapsos lingüísticos nas transcrições). Foi investigando esse processo que Freud encontrou espaço para a conceituação do inconsciente, a partir da distinção entre sonho manifesto e sonho latente, e entre interpretação dos sonhos e "trabalho dos sonhos" [Traumarbeit]. Por isso, na Traumdeutung há dois capítulos complementares: o quinto, sobre "o material e as fontes dos sonhos"; e o sexto, no qual Freud analisa e conceitua os vários procedimentos de reformulação efetuados pelo processo de "elaboração". Descontada a intenção psicanalítica e a importância teórica dessa descoberta, sobra lugar para a sua apropriação literária, justamente em um momento em que as pretensões do Eu autoconsciente haviam sido abaladas pelos delírios e arrebatamentos do modernismo Jugendstil. Basta lembrarmos de Arthur Schnitzler, reconhecido pelo próprio Freud como seu "duplo", e a quem estimava como "um explorador das profundezas psicológicas, tão honrado, imparcial e objetivo quanto possível". ${ }^{264}$ Como podemos notar pelo uso dos adjetivos, diante dos sonhos a investigação científica busca desde o início um correlato na objetividade da elaboração literária, para além do caráter manifestamente "irracional" de seu objeto.

Nos protocolos de Adorno, a intenção seria expor essa "objetividade" por si mesma, sem que uma segunda interferência do sujeito pudesse dispor sobre o sonho como "material" para uma elaboração ainda posterior, agora com finalidade estética. O modelo de Adorno parece ter sido Benjamin, como se percebe no ensaio sobre os aforismos de Rua de mão única, alguns deles também próximos a protocolos oníricos:

Para essa forma filosófica era essencial encontrar uma camada, no espírito, onde imagem e linguagem se unissem. Essa camada é a do sonho. Por isso, o livro contém inúmeros protocolos e reflexões sobre sonhos. Neles, a primazia é dada aos conhecimentos extraídos da zona dos sonhos. Mas esse procedimento tem pouca semelhança com a interpretação dos sonhos freudiana, à qual Benjamin por vezes alude. Os sonhos não são tomados como símbolos da atividade mental inconsciente, mas sim apreendidos literal e objetivamente. ${ }^{265}$

O importante seria o conteúdo manifesto e não o conteúdo latente, já que por sua mera forma a exposição do sonho se tornaria uma via de conhecimento não apenas do sujeito, mas também da realidade, por mais absurda que ela possa aparecer nos sonhos - ou justamente por isso, em analogia com o modo como as vanguardas estavam colocando em questão a própria consistência do "sentido" e dos fundamentos tradicionais da obra de arte orgânica.

Em um trabalho filosófico da década de 1920, quando Adorno buscava encontrar um lugar, no interior da determinação transcendental das faculdades, para o inconsciente, um trecho se destaca: "É de especial importância o reconhecimento, por Freud, de que um de seus pressupostos seria o fato de os sonhos terem um sentido". ${ }^{266}$ Esse sentido próprio, nada óbvio,

\footnotetext{
${ }^{263}$ Sigmund Freud, Die Traumdeutung, Studienausgabe, Frankfurt am Main, Fischer, 1989, v. 2, p. 479-80.

${ }^{264}$ Carta de Freud a Schnitzler em 14.5.1922, reproduzida em Renato Mezan, Freud, pensador da cultura. São Paulo, Companhia das Letras, 2006, p. 681.

${ }^{265}$ Theodor W. Adorno, "Benjamins 'Einbahnstraße", in Noten zur Literatur IV, Gesammelte Schriften 11, op. cit., p. 680.

${ }^{266}$ Idem, "Der Begriff des Unbewussten in der transzendentalen Seelenlehre", in Gesammelte Schriften I, Frankfurt am Main, Suhrkamp, 1973, p. 231. Adorno apresentaria o trabalho como tese de habilitation, sob orientação de Hans Cornelius, mas acabou desistindo, após severas críticas, em 1927.
} 
abre depois espaço para a interpretação de seu sentido latente. Mas a consideração estética de protocolos de sonhos deve ir além da interpretação psicanalítica, pois essa não daria conta precisamente da relação entre consciente e inconsciente na elaboração da forma artística. Isso fundamenta a crítica, na Teoria estética, das possibilidades da "abordagem psicanalítica" da arte:

As obras de arte são, para a psicanálise, sonhos diurnos; ela os confunde com documentos e os transfere para a mente dos que sonham, enquanto, por outro lado, reduz as obras de arte, para compensar a exclusão da esfera extramental, a elementos materiais brutos, de um modo, aliás, curiosamente regressivo em relação à teoria freudiana do "trabalho dos sonhos". 267

Nas obras de arte, a dimensão psíquica, ainda que presente e fundamental, mescla-se com a objetividade do material artístico, em um processo de mediação necessário à elaboração da forma.

Essa defesa da objetividade do protocolo abre espaço para a reflexão sobre os limites da expressão da subjetividade moderna, em uma questão que acaba se impondo: afinal, quem sonha? Nos "monogramas" das Minima moralia encontramos uma pista: "Entre 'apareceu-me em sonho' [es träumte mir] e 'eu sonhei' [ich träumte] encontram-se as idades do mundo. Mas qual é mais verdadeiro? Assim como os espíritos não enviam o sonho, assim tampouco é o Eu que sonha". ${ }^{268}$ Com o processo de desencantamento do mundo, as imagens oníricas deixam de ser atribuições externas (ligadas ao mundo mítico dos espíritos) e passam a ser entendidas como expressão do próprio $\mathrm{Eu}$, que a psicologia filosófica desde Kant entende como um aglomerado autoconsciente de faculdades do conhecimento. Mas esse Eu, argumenta Adorno, mostra-se mais frágil do que se pensa, já que o material dos sonhos configura-se numa instância pré-egoica, e sua elaboração enquanto forma incorpora uma dimensão necessariamente intersubjetiva, a da linguagem e dos modos de expressão literários. É como se o processo de constituição do eu-lírico se reproduzisse na configuração de um "euonírico" (Traum-Ich), que não pode sem mais ser identificado com o indivíduo que relata o sonho. Agora é possível entender o alcance da reflexão de Adorno sobre o surrealismo, uma vez que a subjetividade ali expressa deixa de ser meramente individual e, no confronto com o material também histórico, adquire objetividade e se eleva a modo de conhecimento do mundo.

Mas isso vale também para os protocolos do próprio Adorno? No texto em que revê o surrealismo, ele demonstra enorme interesse pelos procedimentos artísticos do movimento, mas abdica deles quando se contenta com a mera transcrição protocolar de seus sonhos. Aqui, como em Minima moralia, a intenção é elevar o relato da experiência subjetiva, não meramente individual, a momento de exploração das contradições da "vida danificada", já que as imposições do momento histórico determinam o próprio sujeito, até mesmo no que ele tem de mais íntimo, no caso, a vida onírica (um argumento similar vale para a relação entre lírica e sociedade, como discute Adorno em sua importante palestra sobre o tema ${ }^{269}$ ). Isso fica mais claro quando acompanhamos alguns temas recorrentes do livro, em sonhos que revelam ao leitor o modo como os desejos manifestados pelo "eu-onírico" acabam sendo imediatamente reconfigurados por contextos que impedem qualquer satisfação.

Em vários momentos do livro aparece a imagem do bordel, local que se confunde com hotéis e casas de espetáculo, e nos quais a relação entre sexo e mercadoria está dada desde o início:

\footnotetext{
${ }^{267}$ Idem, Aesthetische Theorie (GS-7), Frankfurt am Main, Suhrkamp, 1970, p. 20. Ed. port., Idem, Teoria estética, trad. Artur Morão, Lisboa, Edições 70, 1982. p. 19 (modificada).

${ }^{268}$ Idem, Minima moralia (GS-4), Frankfurt am Main, Suhrkamp, 1996, p. 217. Ed. bras., Idem, Minima moralia, trad. Luiz Eduardo Bicca, São Paulo, Ática, 1993, p. 167.

${ }^{269}$ T. W. Adorno, "Palestra sobre lírica e sociedade", in Notas de literatura I, op. cit., p. 65-89.
} 
Encontrava-me em Paris sem qualquer dinheiro, mas queria ir a um bordel especialmente elegante [...]. Ali no bar, sem ter visto sequer uma menina, eu realmente comi algo [verzehren, jogo de palavras também no original], um grande bife, que me agradou tanto que acabei esquecendo todo o resto. Vinha com molho branco. ${ }^{270}$

A sintaxe quebrada, as relações entre palavras que vão se acumulando como sucessão de imagens, tudo isso era sem dúvida percebido por Adorno, consciente dos elementos de deslocamento e condensação que "trabalham" cada sonho. Mas ele não os comenta, apenas transcreve protocolarmente o sonho, evitando até mesmo a reformulação da breve narrativa nele contida. Em outro sonho, a dimensão de controle total, que dificulta a satisfação, é ainda mais presente:

Eu visitava um bordel americano: tratava-se de um estabelecimento grandioso e esnobe. Mas quem entrava tinha de enfrentar infindáveis formalidades "to register", preencher questionários e falar com a diretora, com sua assistente, e finalmente com a responsável pela seção de vendas [...]. Havia não mais que cinco ou seis meninas, não especialmente notáveis e até mesmo feias. Apenas uma, que se penteava nua na cama, me pareceu bonita. Ela se chamava Ead.

Nesse ponto (como ocorre freqüentemente no livro), o motivo de determinada ação ou nome é apresentado ao leitor entre parênteses, algo comum também em Freud e Breton: "[Motivo: Wildgans, Sonetos a Ead. Na noite anterior eu havia escrito um soneto para R.]". Surge então uma imagem inesperada, que lembra as mulheres etéreas pintadas por Magritte: "Ela só tinha um problema, era inteiramente de vidro, ou talvez do tecido elástico e transparente do qual são feitos meus novos suspensórios. Mesmo sua cabeça se deixa ver através. Mas nem por isso ela estava morta, tinha uma espécie de vida, embora não propriamente uma". ${ }^{271}$ A relação entre a satisfação prometida e a burocracia que impede a realização da "venda"; a menina transparente e sua "espécie de vida", percebida como um "problema" pelo eu-onírico; a comparação surpreendente com o material do suspensório; a relação com a amante real, a quem Adorno havia escrito um soneto no mesmo dia, tudo isso exige interpretação, e uma constelação de sentidos e relações possíveis ressoa na mente do leitor a cada frase. Mas a forma protocolar, como em um conto de Kafka ou uma peça de Beckett, resiste à interpretação, confiando na pura exposição dos elementos como garantia da tensão que lhe dá sentido.

Antes mesmo de ser interpretado, no entanto, o sentido intuído pelo sonho age sobre o sujeito, e isso transparece não apenas nas reações físicas do próprio Adorno, meticulosamente descritas, mas também como ensinamento ou sentimento derivado. São marcas do contato entre o sono e a vigília, que funcionam de certa forma como "moldura" para o texto do protocolo. Nessa tênue fronteira se confundem o depoimento íntimo e a declaração ao leitor: "Acordei com a morte"; 272 "Acordei com medo e horror"; ${ }^{273}$ "Fui tomado por tamanho horror e asco, que despertei com o sentimento de mal-estar físico". ${ }^{274}$ No final do impressionante sonho em que acompanhamos a tortura sádica de "um encantador menino de doze anos", pode-se ler "Acordei com terror indescritível, pulso batendo muito forte". ${ }^{275}$ Mas o contrário também ocorre, como no sonho com a amiga Luise Rainer, "Acordei com um sentimento de

\footnotetext{
${ }^{270}$ Idem, Traumprotokolle, op. cit., p. 8 (Oxford, 10 de março de 1937).

${ }^{271}$ Idem, ibidem, p. 25 (Los Angeles, 10 de janeiro de 1943).

${ }^{272}$ Idem, ibidem, p. 7 (Frankfurt, janeiro de 1934).

${ }^{273}$ Idem, ibidem, p. 17 (Los Angeles, início de julho de 1942).

${ }^{274}$ Idem, ibidem, p. 33 (Los Angeles, final de março de 1944).

${ }^{275}$ Idem, ibidem, p. 52 (Los Angeles, 4 de fevereiro de 1946).
} 
felicidade, que ainda perdurava quando liguei para ela", 276 ou nos vários momentos em que Adorno acorda às gargalhadas. Entre os dois pólos, há espaço para a tomada de consciência sobre si mesmo, num processo de reflexão que começa durante o sonho e só termina no momento do despertar: "Eu sabia: tudo o que fiz no sonho tinha o objetivo da autodestruição. Mas o próprio sonho queria me alertar sobre isso, e me curar". 277

Breton oferece um interessante contraponto às dificuldades de representação literária dessa sensação de transbordamento do sonho no estado de vigília. Em Nadja, obra na qual o autor-narrador entrega-se ao acaso e ao relato oscilante de seus pensamentos e caminhadas por Paris, encontramos o seguinte trecho: "De manhã, ao despertar, tive mais trabalho que de costume para desvencilhar-me de um sonho tão infame que não vejo a menor necessidade de o transcrever aqui, pois decorre em grande parte de conversas que tive ontem, sobre assunto inteiramente diverso". ${ }^{278}$ Mesmo sem transcrever o sonho, o narrador passa a divagar sobre o modo como as impressões recolhidas durante o dia são reconfiguradas em imagens interessantes, que podem ser experimentadas, "acima do bem e do mal" tanto durante o sono quanto "no que se lhe opõe muito sumariamente sob o nome de realidade". ${ }^{279}$ No lugar do protocolo, temos a busca dos nós que ligam o inconsciente aos acontecimentos e referências da vida cotidiana, sem que o autor se esqueça, entretanto, de que "a vida é diferente do que se escreve". 280

Mas a pergunta inicial do livro de Breton é “Quem sou?", enquanto o livro dos sonhos de Adorno poderia se articular em torno de outra questão: “ainda estou vivo?". A epígrafe já anuncia: "O sonho é negro como a morte". ${ }^{281} \mathrm{E}$ os diversos protocolos sobre o tema demonstram que a morte também é diferente do que se escreve. Na sucessão de sonhos com execuções, vinganças, crucificações e torturas (nas quais o eu-onírico se alterna como sujeito e objeto da ação, dependendo do caso), o desejo sexual também se faz presente. No entanto, assim como ocorre nos sonhos de bordel, a satisfação é perturbada pela atenção aos detalhes e à completa organização dos atos:

Cena de execução. Se as vítimas eram fascistas ou antifascistas, não estava claro. De qualquer forma, era uma turma de jovens nus e atléticos [...]. A execução ocorria segundo o princípio do self-service. Cada um se encaminhava a uma guilhotina automática, sem que uma ordem fosse dada, e voltava sem cabeça, cambaleava alguns passos e caía morto. [...]. Assisti a tudo sem me emocionar, mas acordei com uma ereção. $^{282}$

O tom protocolar confere objetividade à declaração mais íntima, e o leitor acompanha em imagens vivas a articulação da morte e do prazer, instâncias que configuram a própria subjetividade, enquanto princípios fundamentais do instinto (Trieb). Mesmo quando tentado a relacionar o conteúdo dos sonhos com a biografia de Adorno ou com temas desenvolvidos em sua obra, o leitor é levado pela forma a uma universalização da experiência sedimentada no relato, já que ela ao mesmo tempo antecede e vai além da mera experiência individual.

Ainda que compartilhem a intenção de expor, por meio do sonho, os processos nãosubjetivos de formação da subjetividade, os livros de Adorno e Breton se distinguem justamente pelo que separa a obra de arte da transcrição "literal e autêntica". Esse é um tema importante da própria Teoria estética:

\footnotetext{
${ }^{276}$ Idem, ibidem, p. 35 (Los Angeles, 10 de agosto de 1944).

${ }^{277}$ Idem, ibidem, p. 49 (Los Angeles, 14 de outubro de 1945).

${ }^{278}$ A. Breton, Nadja, op. cit., p. 673-5, ed. bras., op. cit., p. 49.

${ }^{279}$ Idem, ibidem, p. 675, ed. bras., op. cit., p. 51. (modificada).

${ }^{280}$ Idem, ibidem, p. 689, ed. bras., op. cit., p. 68.

${ }^{281}$ T. W. Adorno, Traumprotokolle, op. cit., p. 6.

${ }^{282}$ Idem, ibidem, p. 43 (Los Angeles, 14 de julho de 1945).
} 
Se a arte tem raízes psicanalíticas, são as da fantasia na fantasia da onipotência. Nela atua, porém, também o desejo, presente na obra, de produzir um mundo melhor. Isso libera a dialética total, ao passo que a consideração da obra de arte como uma linguagem do inconsciente, meramente subjetiva, não consegue apreendê-la. ${ }^{283}$

Como, segundo o próprio Adorno, "as imagens dialéticas do surrealismo são as de uma dialética da liberdade subjetiva em uma situação de não-liberdade objetiva", ${ }^{284}$ então a expressão literária dessa contradição, justamente quando parece obsoleta, permanece como imagem da "promessa de felicidade". E essa felicidade, mais do que mero desejo individual a ser investigado pela análise posterior, sedimenta na própria forma uma intenção política, pois se refere à sociedade como um todo:

Na medida em que a arte se constitui mediante a experiência subjetiva, o conteúdo social penetra nela essencialmente; não, porém, de modo literal, mas modificado, camuflado, indistinto. Tal é a verdadeira afinidade da obra de arte com o sonho, que nada tem a ver com algo psicológico. ${ }^{285}$

Nesse ponto, Breton poderia invocar Hegel para dar conta da dialética presente nos relatos de sonhos do próprio Adorno, lembrando que toda forma de expressão é ela mesma mediada, e o protocolo, como forma, também envelhece e assume outro sentido, para além da intenção de quem o escreve. Paradoxalmente, a busca de uma apreensão literal das imagens oníricas, com a mínima intervenção do sujeito, assume hoje em dia um caráter muito mais literário do que científico-filosófico. O próprio Breton, que exaltava, como vimos, esse "interesse sistemático de pesquisa" dos sonhos, nem por isso deixou de se exprimir em prosa refinada e envolvente, até quando se pretendia um "modesto aparelho registrador". ${ }^{286}$ Mesmo se muitas das referências de suas obras não fazem sentido ao leitor atual, a força das imagens configuradas artisticamente pelo Surrealismo ultrapassa os limites de sua intenção datada. $\mathrm{O}$ impacto dessas montagens criadas e recriadas pelos artistas tem um alcance que o próprio Adorno testemunha, para além de suas considerações sobre o movimento, num dos sonhos mais curiosos do livro: "Eu possuía um luxuoso volume ilustrado sobre o Surrealismo, e o sonho nada mais foi do que a exata representação de uma dessas ilustrações". ${ }^{287}$

\footnotetext{
283 T. W. Adorno, Aesthetische Theorie (GS-7), op. it., p. 22, ed. bras., Teoria estética, op. cit., p. 20 (modificada).

${ }^{284}$ Idem, "Revendo o surrealismo", op. cit., p. 138.

${ }^{285}$ Idem, Aesthetische Theorie (GS-7), op. cit., ed. bras., op. cit., p. 459.

${ }^{286}$ A. Breton, "Manifeste du surrealisme", op. cit., p. 330, ed. bras., op. cit., p. 42.

${ }^{287}$ T. W.. Adorno, Traumprotokolle, op. cit., p. 52 (Los Angeles, 18 de fevereiro de 1948).
} 